\title{
Human Potential and Quality of Life in Siberian Regions: from Degradation to Growth
}

\author{
Anton V. Efimov and Valerii S. Efimov* \\ Siberian Federal University \\ 79 Svobodny, Krasnoyarsk, 660041, Russia
}

Received 07.07.2016, received in revised form 16.08.2016, accepted 21.09.2016

Based on statistical data, the analysis shows that there has been a significant decline in human potential and quality of life in Siberia in the course of the last two decades in comparison with the average indices.

The results of the analysis prove that human potential and quality of life in Siberia in recent decades have been in steady decline: there is a reduction in the relative size of the Siberians' income; the number of the poor in the Siberian federal district exceeds the average values; in general the gap between Siberia and Russia has been increasing as per the mortality rate on social grounds (the number of suicides and alcohol poisonings per 100 thousand people); a lower share of people with higher education in Siberian economy is still preserved in comparison with the average indices. There is still a higher level of crime in Siberia as compared to the average for Russia. In recent years there has been a significant growth of "violent" crime indices (murders, rapes, robberies) as compared to the average values.

The revealed tendencies show that in recent years there has been displacement of Siberia to the periphery of the country's economic, social and cultural development. Siberia is becoming less developed crime periphery of the Russian Federation.

The article analyzes the conditions of "human capitalization", current situation of human capital and potential in Russia and Siberia. The situation, developing in Russia, does not in many respects favour the population's entrepreneurial and social activity that is manifested in sharp slowdown in the country's economic development within the period of 2012-2015.

The following provisions of the human capital growth policy in the Siberian federal district are formulated:

- human capital development is a priority of Siberia's strategic development;

- a priority of the human capital increase policy is to support social activity and entrepreneurship;

- the subjects of the federation should have wide powers and opportunities for human capital development in the regions;

- it is necessary to expand a range of demographic and migration policies measures aimed at supporting birth and family and stimulating the population's migration inflow to Siberia;

- it is vital to support the metropolitan agglomerations development in Siberia, the agglomerations being the environment that ensures human capitalization to the maximum extent.

Keywords: quality of life, human potential, human capital, social policy, regions of Siberia, Siberian federal district.

(C) Siberian Federal University. All rights reserved

* Corresponding author E-mail address: efimovant@gmail.com; efimov.val@gmail.com 


\section{Introduction}

A key factor of the countries' and regions' socio-economic development is human potential; its importance is comparable to investment opportunities, industrial and infrastructural potential of the territory. Significance of human potential in the regions, the development of which is constrained by spatial features and lack of developed infrastructures, is especially high. This is typical for Siberia.

The formation of the human capital concept started in the second half of the XX century. Currently, the "human capital" phrase has a broad range of meanings: from a metaphorical nomination of a human value to nomination of clear and operational ideas about the value of a human's qualification and "creative productivity". The economic concept of human capital and the underlying theoretical model were suggested by $\mathrm{T}$. Schultz (Shultz, 1961, 1963, 1971) and G. Becker (Becker, 1964, 2003), the Nobel Prize winners. In Russia the issue of human capital is presented in the works by R.I. Kapeliushnikov (Kapeliushnikov, 2006, 2008), V.E. Gimpel'son (Gimpel'son, Kapeliushnikov, 2011), I.V. Soboleva (Soboleva, 2009), Iu. Korchagin (Korchagin, 2004, 2005).

In the theory and practice of management there are several approaches basing on various notions of "human values", the notions being "human resources", "human potential" and "human capital".

Attitude to a human as a labor resource is typical of the early industrialization era; a human as a "labor resource" is perceived as a homogeneous and often superfluous human mass, a part of which can be selected and involved in the production at a minimum cost (adaptation, reward training).
"Human potential" means a person's ability to carry out complex activities, have a high income, a high level of education and maintain his/her health. The United Nations Development Programme relies on the human development index $(\mathrm{HDI})^{1}$, which includes the following indices and their derivatives: life expectancy, the population's level of education, gross national income per capita. The idea of human potential appeared in the late industrialization period with the advent of high-tech industries and consumption development.

The idea of a human as a specific "capital" is most typical of the companies in the postindustrial economy with a human's qualification, initiative, and creativity as defining factors of the companies' competitiveness and strategic sustainability. According to T. Stoun'er, "human capital" implies a special role of a human as a core basis of productive forces, which makes it possible to create and maintain complex production systems including equipment, technological knowledge and means of their practical application, organizational improvements, knowledge of business conditions, and market opportunities (Stoun'er, 1986).

The purpose of this article is to study the peculiar features of changes in human potential of the leading regions of the Siberian federal district (SFD) in post-Soviet Russia; to formulate proposals for the state policy aimed at its growth. The data of the Federal State Statistics Service (Rosstat) were used for the analysis of changes in human potential. They make it possible to assess the population's living conditions and the level of human potential development: total population, population's income, life expectancy, level of the population's education, poverty rate, death 
rate as per external (social) reasons, crime rate, "violent" crime rate. The analysis was carried out on the basis of the comparison of the indices for Siberian regions with the national ones. This enabled to abstract of the trends of the nationwide changes and focus on the relative changes in the situation in Siberia.

\section{Human potential}

of the Siberian federal district:

\section{key features and trends}

Intensive development of Siberia in the second half of the XIX century was the most important task of the Soviet Union. It implied the development of new oil and gas, ore and coal deposits; Baikal-Amur Railroad building; construction of the largest hydroelectric power stations; formation of Siberian nonferrous metallurgy; regional airports network development; urban and industrial infrastructure development. Solution of this task was provided for considerable investments, the population's flow to large-scale construction projects, new production and service enterprises. The population of Siberia increased by almost 1.5 times during this period (from 15 million people (the year of 1950) to 21.1 million people (the year of 1990)). These were mostly young, active people.

$14.28 \%$ of Russia's population (21.1 million people) resided in Siberian regions in 1990; investment in Siberia's development reached 14.8\% of nationwide investments; the average income of the residents of Siberia was $98 \%$ of the Russians' average income; the number of the poor ${ }^{2}$ amounted to 6.8 million people (1995) that made $32.8 \%$ of the population of Siberia; the crime rate exceeded the national average by $17.6 \%$ (1462 crimes per 100 thousand people in 1990).

Socio-economic transformations in the 1990s led to the collapse of the Soviet Union, which had a negative effect on the development of Siberia, led to the changes in the population's living conditions and reduction of human potential. The latter resulted in a significant migration outflow of the population; decrease in the population's income relative to the national average; rise in mortality rate due to social reasons and rise in crime rate as compared to the average indices, etc. (Efimov V.S., Efimov A.V., 2013a). As for the quality of life criterion, Siberian regions, especially "depressive" ones, are significantly behind the national average and turn into a deep social and economic periphery of the country (Efimov V.S., Efimov A.V., 2013b).

Population. In recent decades there has been a reduction in the total population of Russia by 2.6\%: from 148.0 million people in 1990 to 144.1 million people in 2015. At that the population of the Siberian federal district decreased by $8.5 \%$ : from 21.1 million people in 1990 to 19.3 million people in 2015. A large decrease in the population size occurred only in the Far Eastern federal district (FEFD), the decrease being 23.0\% (from 8.1 million people in 1990 to 6.2 million people in 2015).

There was a significant decline of the Siberian federal district population between 1992 and 2005. It was higher than that in the Russian Federation. The years of 2006-2015 were a period of a relative stabilization of the Siberian population size. During the period of 1990-2015 the population increased only in the Central federal district (CFD), the increase being 2.5\%. All the rest federal districts faced the population decline (Table 1).

Within the period of 1990-2015 there was the population decline in all geographic regions. The exception was Novosibirsk oblast with a slight increase by $0.4 \%$ (11.1 thousand people). The minimum reduction in the population size was registered in Tomsk oblast; the reduction amounted to 1.1 thousand people $(0,1 \%)$.

The maximum population decline within the period of 1990-2015 was registered in 


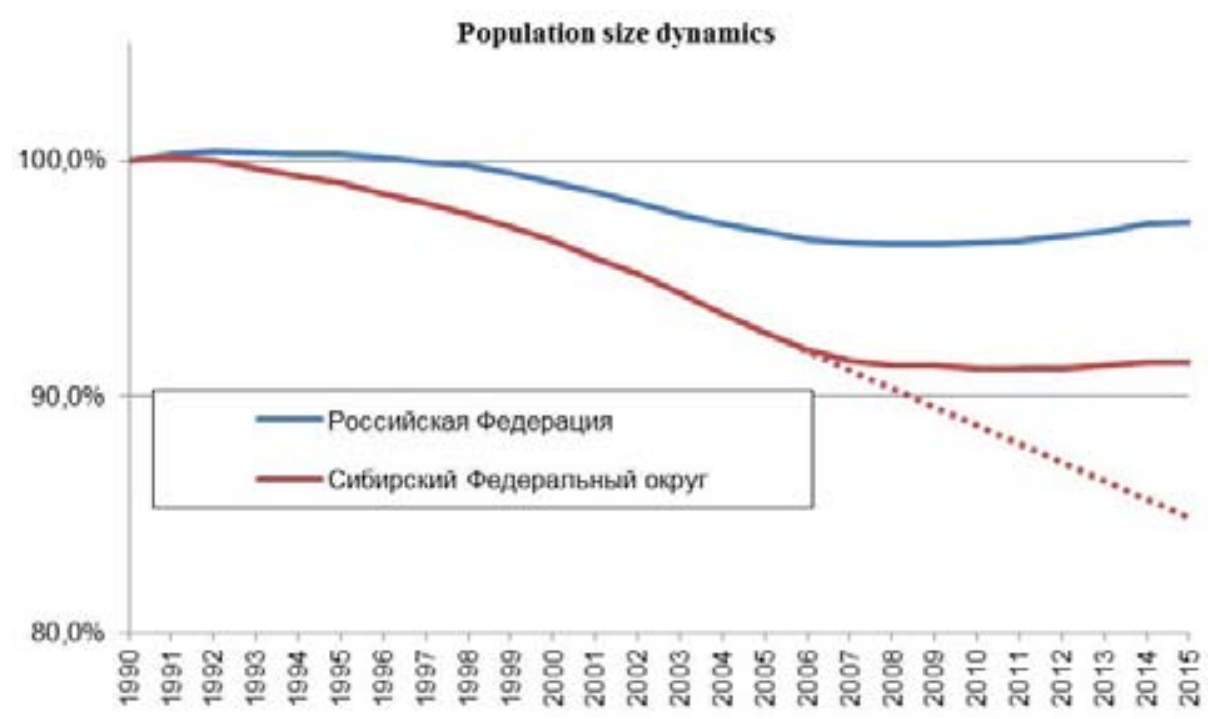

Fig. 1. Dynamics of population size in Russia and the Siberian federal district in 1990-2015 (Source: Federal State Statistics Service ${ }^{3}$ )

Irkutsk oblast (382.1 thousand people (13.7\%)) and Kemerovo oblast (378,7 thousand people $(12,2 \%))$.

\section{Population's income}

Since 1995 the Russians' income in rubles has been increasing annually. Even the crisis year of 1998 (Table 2) was no exception. Whereas in 1995 the average income per capita in the Siberian federal district and Russia amounted to 494 rubles and 516 rubles, respectively; in 2015 the amount reached 23336 rubles (Siberian federal district) and 30255 rubles (the Russian Federation). At that the income of the Siberian federal district population among the federal districts as per the income level ranked the 7th. It was higher than only in the North Caucasian federal district (22.8 thousand rubles); the Volga federal district (26.2 thousand rubles); the Southern federal district (27,0 thousand rubles); the North-Western federal district (32.4 thousand rubles); the Ural federal district (32.6 thousand rubles); the Far Eastern federal district $(36,6$ thousand rubles); the Central federal district (38.7 thousand rubles).
Within the period of 1995-2015 there was a significant decrease in the average per capita income relative to the national average. The income decreased by 18.5 percentage points (PP): from $95.7 \%$ in 1995 to $77.2 \%$ in 2015 .

Krasnoyarsk krai with the population's income of 26.9 thousand rubles, which is $115.1 \%$ of per capita income in the Siberian federal district, and $88.9 \%$ of the national average and Omsk oblast with the population's income of 25.7 thousand rubles, which makes $110.4 \%$ of per capita income in the Siberian federal district and $85.3 \%$ of the national average were the most prosperous regions in the Siberian federal district in 2015 .

Altai krai with the population's income of 21.0 thousand rubles, which is $90.0 \%$ of per capita income in the Siberian federal district and $69.5 \%$ of the national average, and Kemerovo oblast with the population's income of 21.5 thousand rubles, accounting for $92.4 \%$ of per capita income in the Siberian federal district and $71.3 \%$ of the national average, were the most disadvantaged regions in the Siberian federal district in 2015. Yet, in 1995 the population's income in Kemerovo oblast 


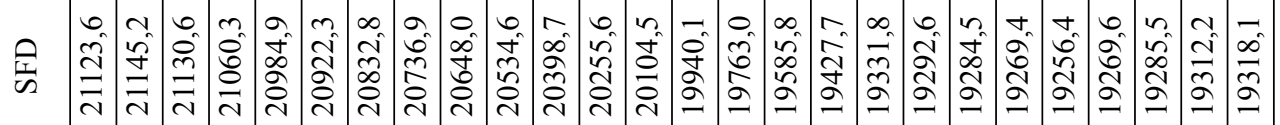

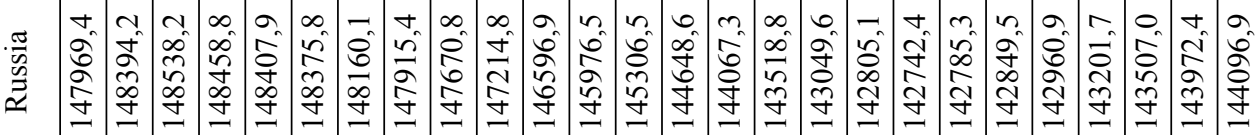

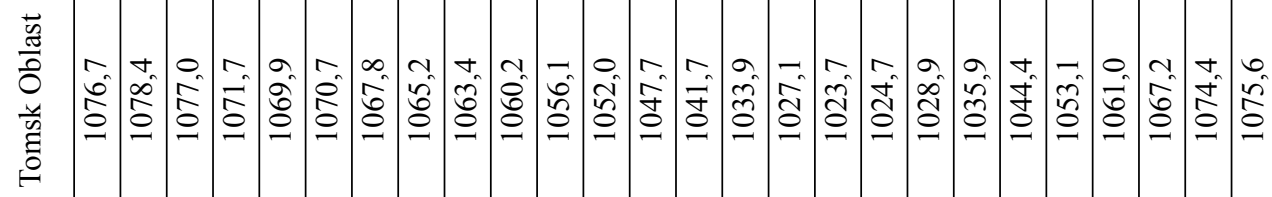

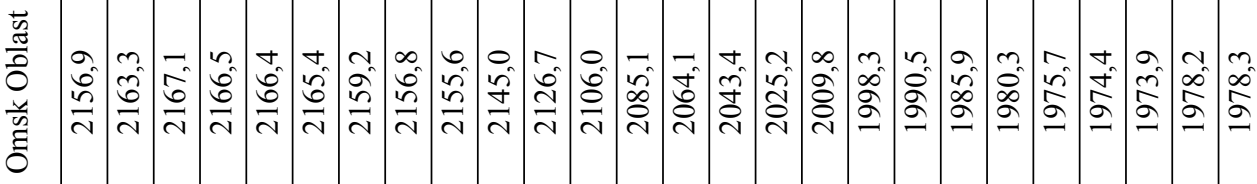

要

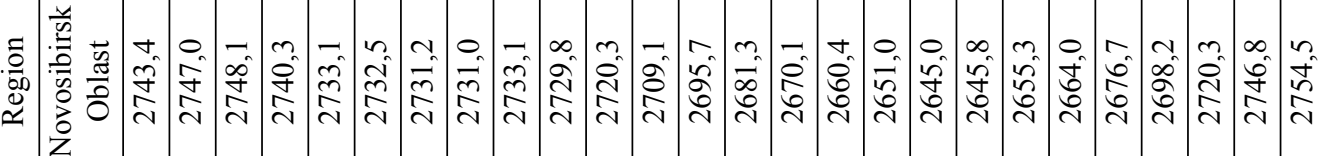

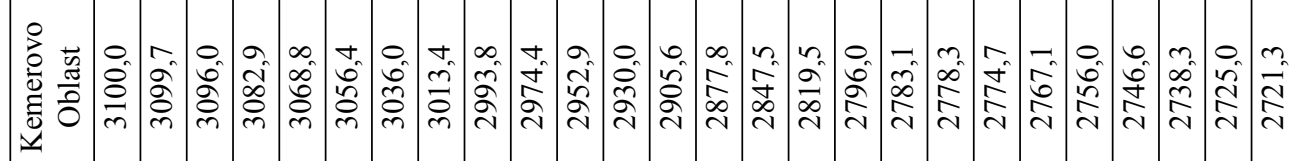

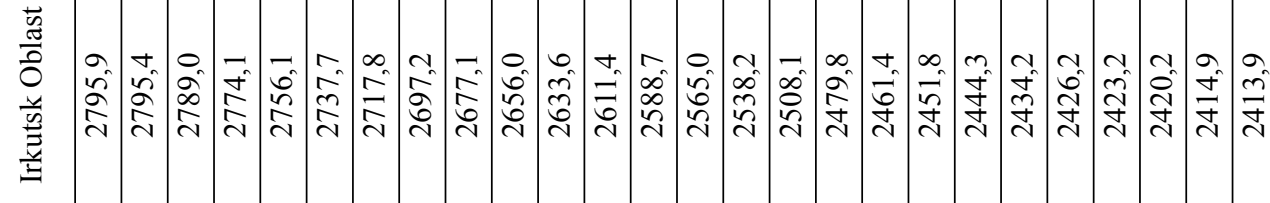

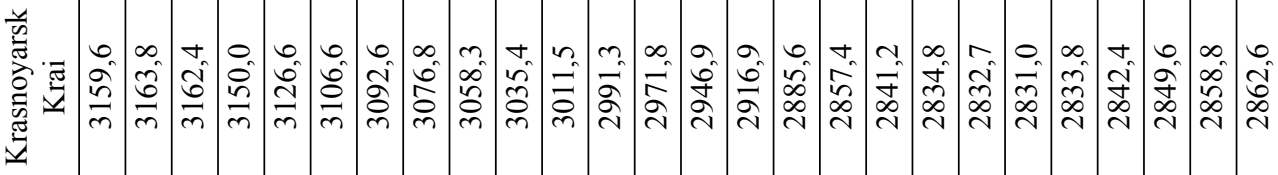

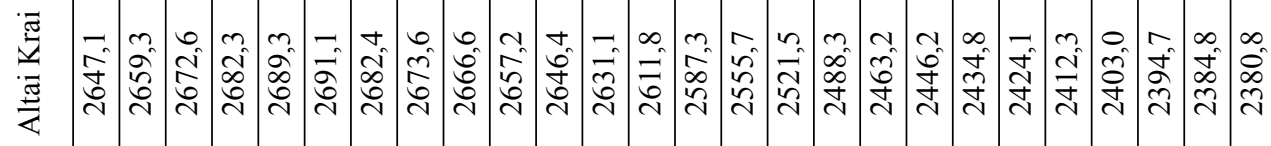

离 


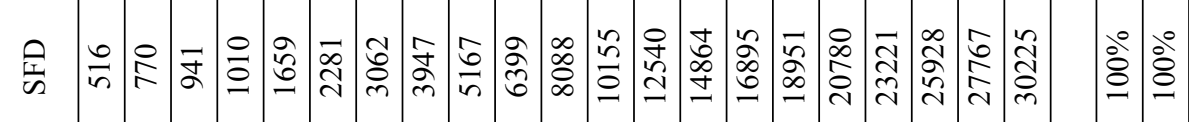

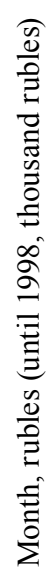

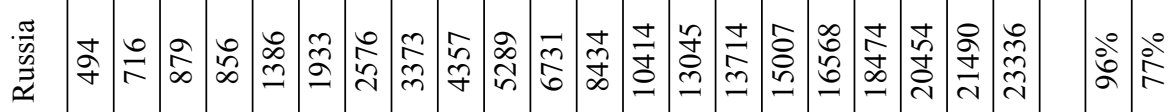

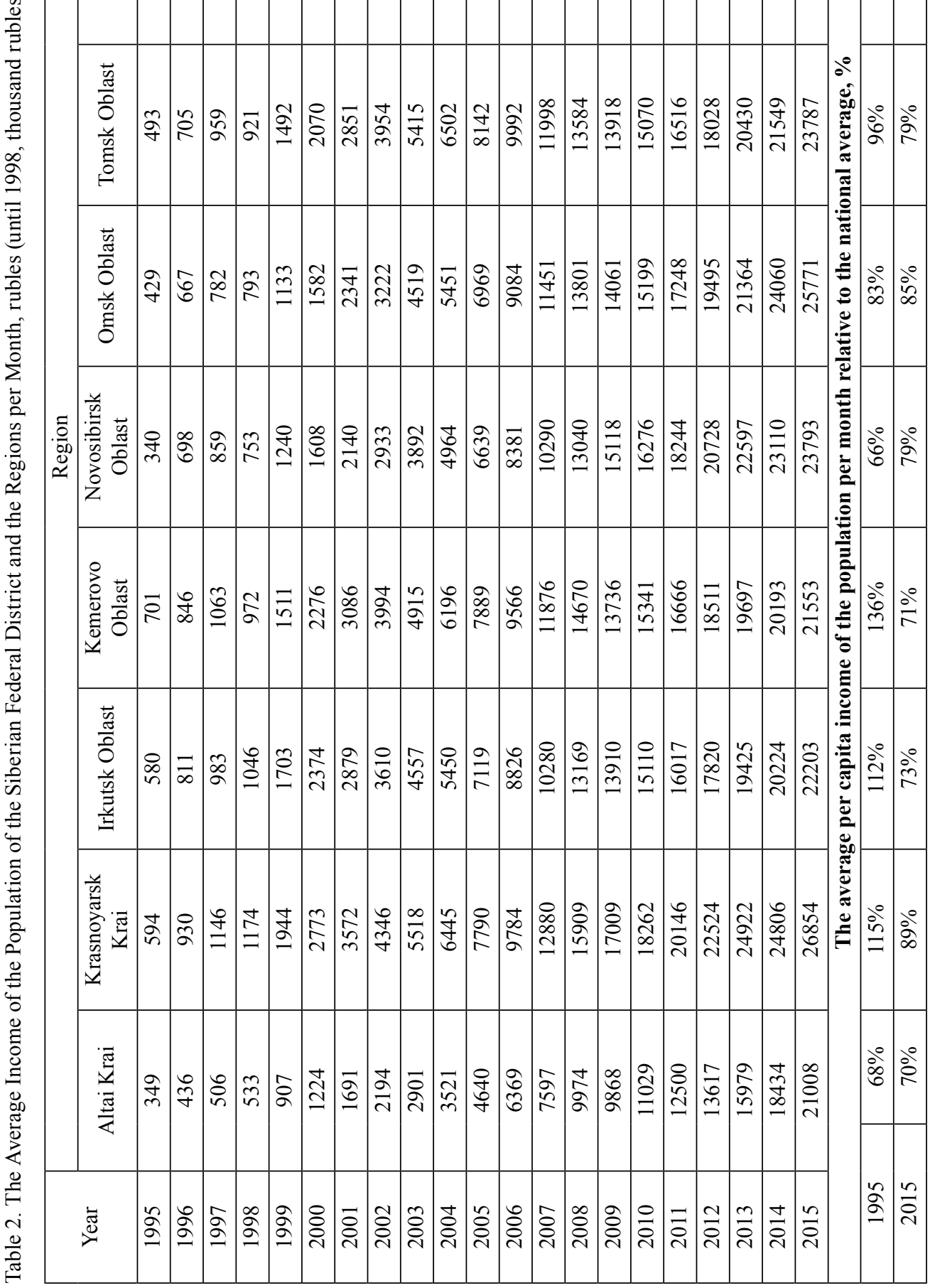


was the highest in the Siberian federal district. It exceeded the average income in the Siberian federal district by 1.4 times and the average income in Russia by 1.35 times.

The year of 2009 was the year of the most dramatic decline in per capita income compared to the national average. This was due to the crisis of 2008. In 2009 the population's income in the Siberian federal district decreased by an average of 7.8 percentage points as compared to the national average in most regions, whereas the population's income in Novosibirsk oblast increased by 1.8 percentage points and the population's income in Kemerovo oblast decreased by 17.4 percentage points as compared to the national average.

\section{Life expectancy at birth}

After a sharp drop in life expectancy in Russia in 1990-1994 (from 69.2 years to 63.9 years (5.3 years)) life expectancy at birth increased up to 67.1 years (1998) and dropped again by 2.2 years up to 64.9 years by 2003 . Then within the period of 2004-2015 there was a steady increase in life expectancy at birth.

The indices of life expectancy at birth in the Siberian federal district reached the level of the national average values of 1990 (69.2 years in Russia) only by 2015 (69.3 years in the Siberian federal district).

Thus, life expectancy in the Siberian federal district during the last 25 years was below the national average values by an average of 1.9 years. (Table 3).

In terms of life expectancy at birth index, in 2015 the Siberian federal district lagged 2.1 years behind the average values, which was equal to the Russian value in 2010-2011. The processes of life expectancy increase in the Siberian federal district are 3-5 years late in relation to the national average.

In 2015 the highest life expectancy among the regions of the Siberian federal district was registered in Tomsk oblast and Novosibirsk oblast. They were 71.3 years (which is comparable with the average value of 71.4 years) and 70.9 years, correspondingly.

The lowest life expectancy in 2015 was registered in Irkutsk oblast. It was 67.4 years (4.0 years lower than the national average).

\section{The level of the population's education}

In the course of the last 24 years there was an increase in the number of people with higher education in Russia: in 1992 the share of people with university diplomas was $16.2 \%$ among the employed in the economy; in 2015 this value increased twice - up to $33.0 \%$ (Table 4). During this period the share of people with higher education among the employed in economy increased by 16.8 percentage points in Russia and by 15.4 percentage points in the Siberian federal district.

In 2015 the lowest share of people with higher education among the employed in the economy was registered in the Siberian federal district (29.1\%), the Volga federal district (30.1\%), the Southern federal district (30.5\%), the Ural federal district $(31.2 \%)$, the North Caucasian federal district (31.3\%), the Far Eastern federal district (32.1\%), the North-Western federal district (33.6\%), whereas the highest share of people with higher education among the employed in the economy was registered in the Central federal district (38.3\%).

In 2015 the leaders in terms of people with higher education among the employed in the economy were Novosibirsk oblast (33.6\%, which is higher than the national average of $33.0 \%$ ) and Tomsk oblast (32.8\%, which corresponds to the average level in Russia).

It was Omsk oblast that was an outsider as per the number of people with higher education among employed in the economy in 2015. The number was $26.8 \%$, which is 6.2 percentage points 


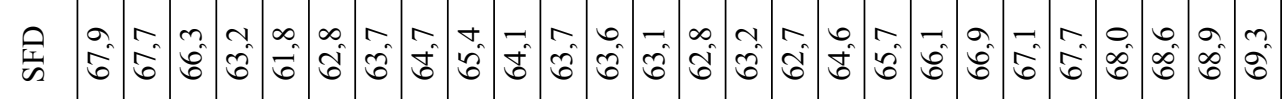

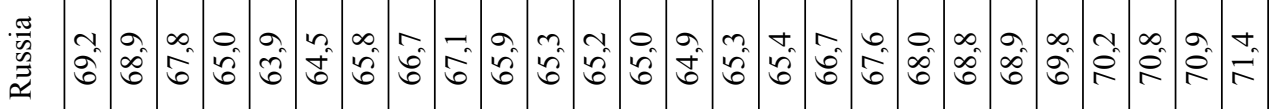

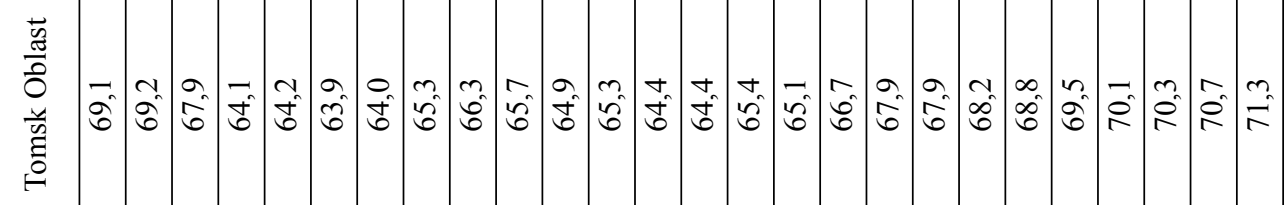

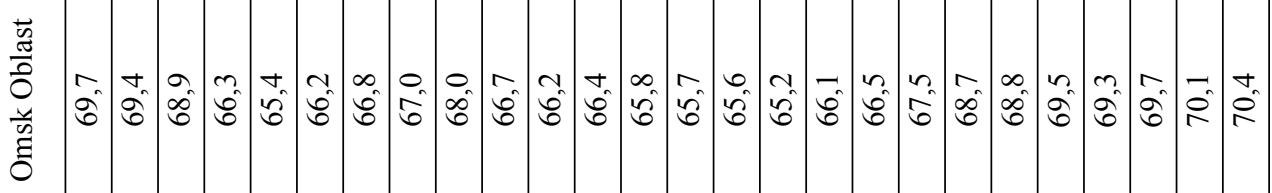

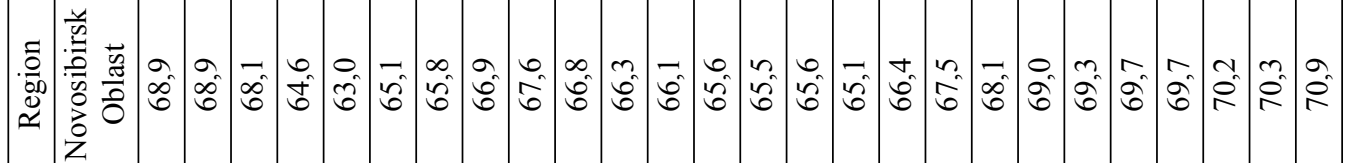

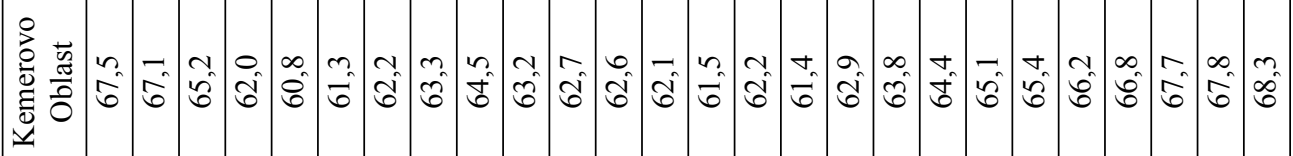

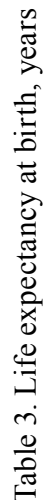

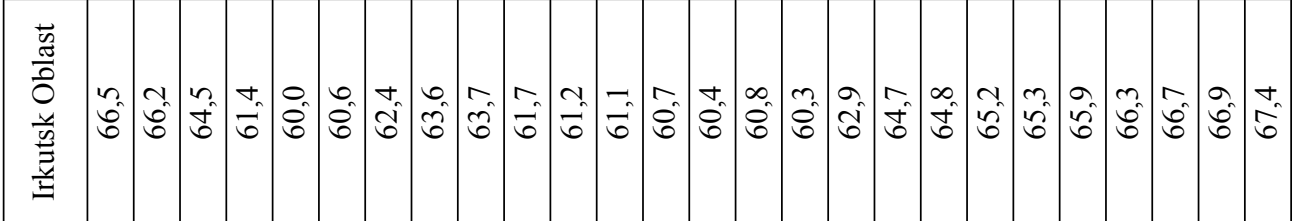

商

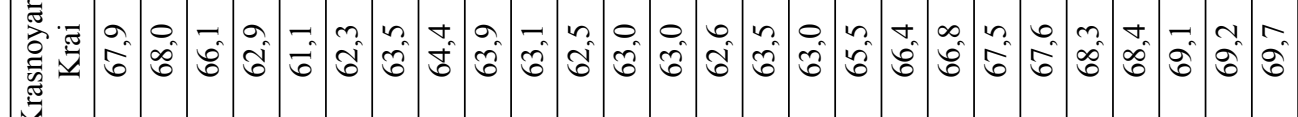

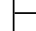

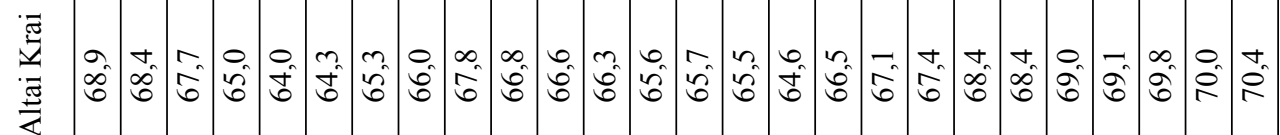

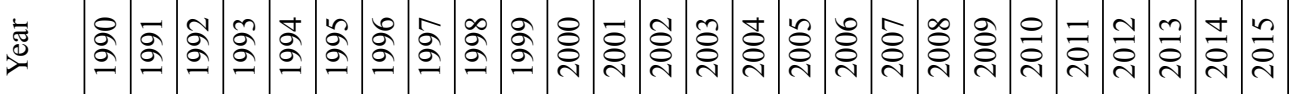




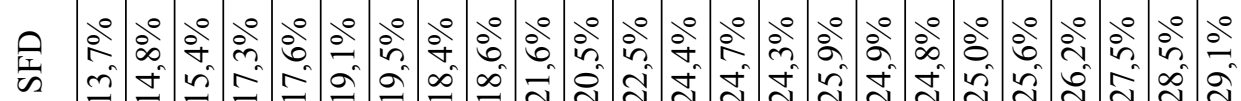

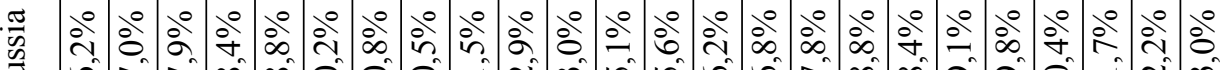
光

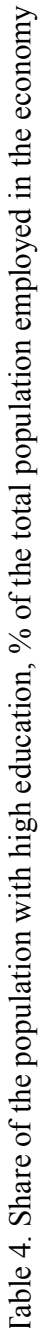

.

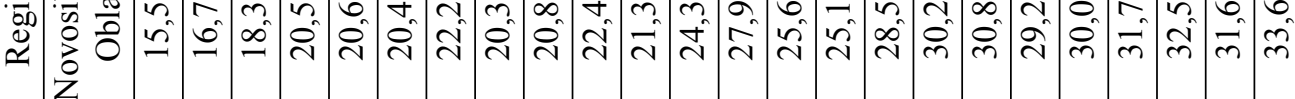

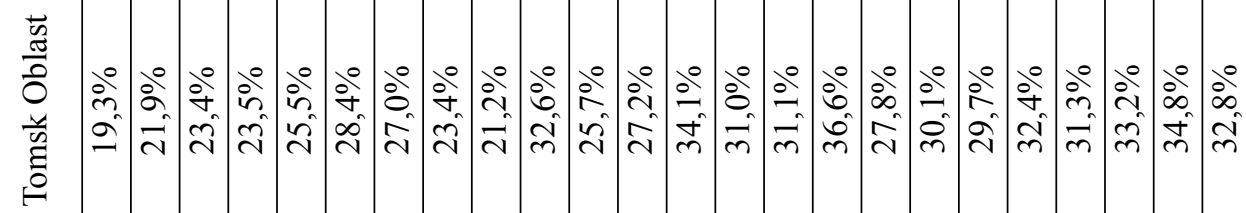

䓂

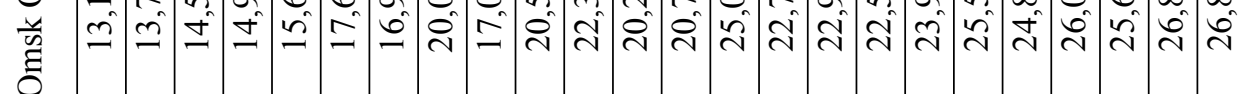
ป

晃 चू

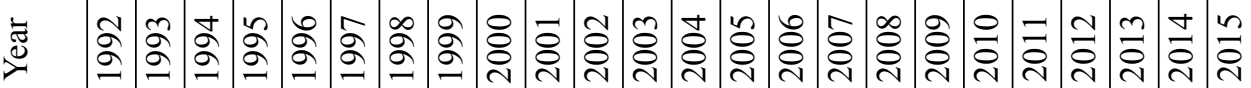


less than the national average values $(33.0 \%)$ and 2.3 percentage points lower than the average for the Siberian federal district.

\section{The poverty rate}

The share of the population with the income below the subsistence level is one of the most important indices of standard of living and an index of social differentiation in society. In all the regions of the Siberian federal district and in Russia on the whole the share of the poor was in steady decline for 19 years (1995-2013), the crisis year of 2008 was the only exception. Yet, from 2014 the share of the poor increased in all the regions of the Siberian federal district and on the average in Russia, and in 2015 there was a sharp jump of increase in the share of the poor by 0.9-3.6 percentage points, such a jump in Russia amounted to an average of 2.1 percentage points.

In Russia the share of the poor decreased by almost 2 times in the course of the 1995-2015 period: from $24.8 \%$ in 1995 to $13.3 \%$ in 2015 . In the Siberian federal district the share of the poor decreased by 14.3 percentage points: from $32.8 \%$ in 1995 to $18.5 \%$ in 2015 (Table 5).

Among the regions of the Siberian federal district the lowest share of the poor in 2015 was registered in Omsk oblast. It was $13.9 \%$, which was slightly higher than the national average $(13.3 \%)$.

The highest share of people with the income below the subsistence level in 2015 was registered in Irkutsk oblast. It was $20.5 \%$, which is 7.2 percentage points higher than the national average and 2.0 percentage points higher than the average value for the Siberian Federal district $(18.5 \%)$.

\section{The population's mortality rate \\ for social reasons}

The mortality rate for social reasons is an important index of social disadvantage. In statistics this index includes mortality from 16 possible reasons, the main ones being suicides, transport accidents, alcohol poisonings. 177.6 thousand people died in Russia in 2015 for social reasons: 25.5 thousand people committed suicide; 15.2 thousand people were poisoned by alcohol ${ }^{4}$.

The increase of mortality because of suicides, alcohol poisoning is an indicator of the social crisis the society and the state are in. In Russia the mortality rate due to suicide and alcohol poisoning in the last 25 years changed from 37.4 cases per 100 thousand people in 1990 to 79.9 cases in the crisis year of 1994 and 69.4 cases per 100 thousand people in the relatively prosperous year of 2002 .

In 2015 the mortality rate for social reasons in Russia (suicides and alcohol poisonings) reached the level of 28.3 people per 100 thousand people that is lower than the values of 1990 (Table 6).

In 2015 the largest number of deaths for social reasons (suicides, accidental alcohol poisonings) among all federal districts was recorded in the Siberian federal district (41.3 deaths per 100 thousand people which is 1.5 times higher than the national average); the Ural federal district ranked the second (36.4 deaths per 100 thousand people); the Volga federal district ranked the third ( 33.7 deaths per 100 thousand people); these were followed by the Far Eastern federal district (32.8 deaths per 100 thousand people); the North-Western federal district (30.7 deaths per 100 thousand people); the Central federal district (22.7 deaths per 100 thousand people); the Southern federal district (13.6 deaths per 100 thousand people) and the North Caucasian federal district (5.7 deaths per 100 thousand people).

There was an increase in mortality for social reasons (suicides, alcohol poisonings) relative to the national average in the Siberian Federal district within the period from 1990 to 2015: from $117.1 \%$ in 1990 to $146.0 \%$ in 2015 (the increase of 28.9 percentage points). 


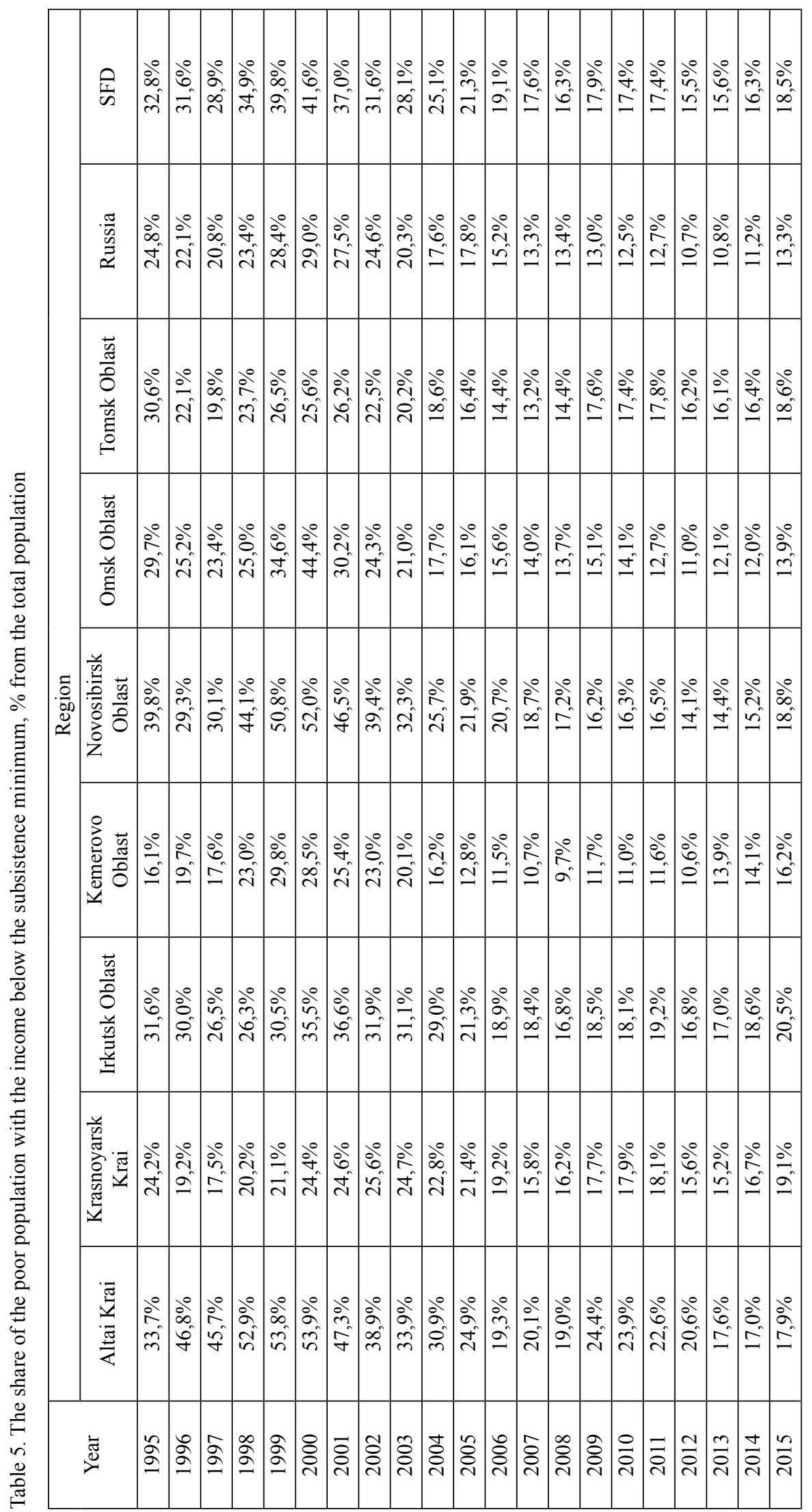




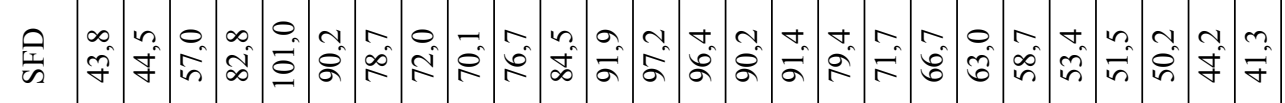

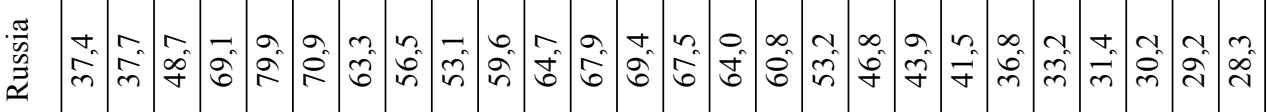

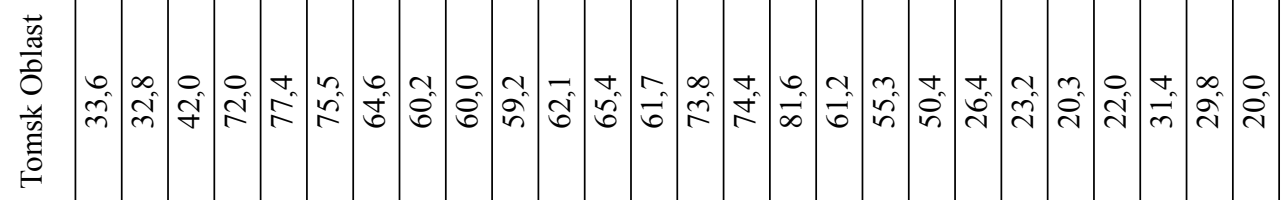

$\frac{0}{\stackrel{0}{0}}$

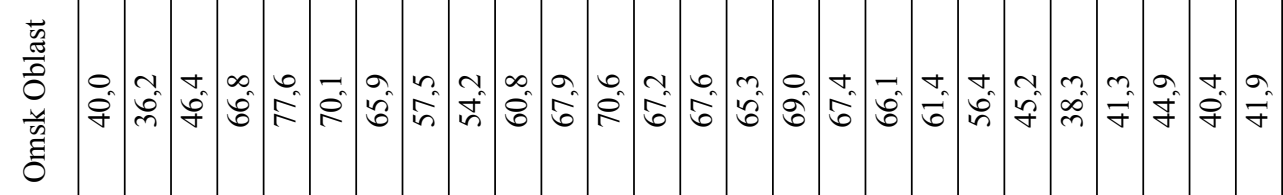

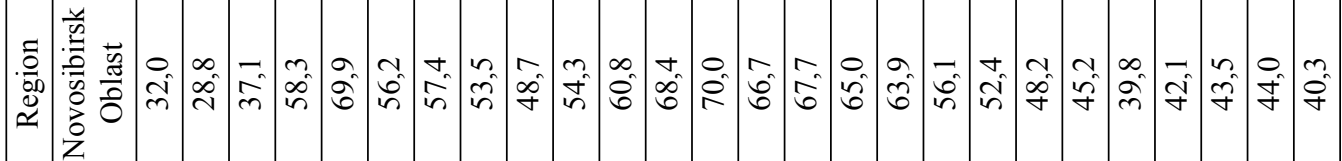

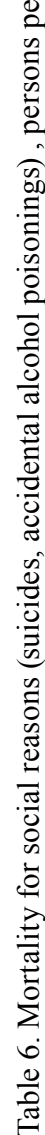

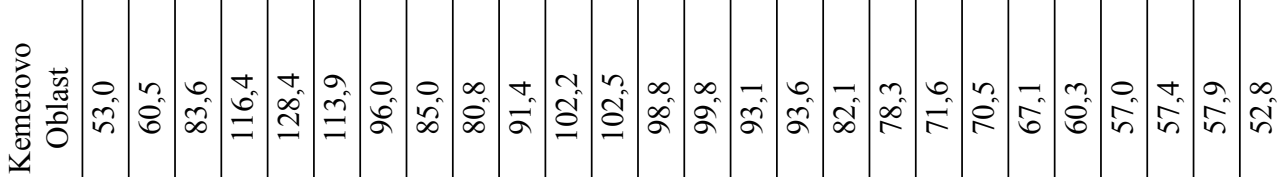

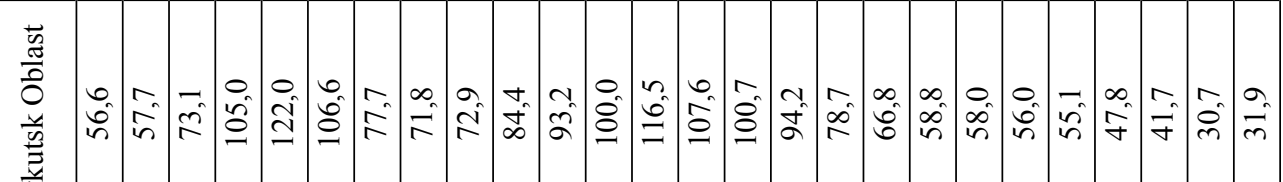

言

嘭

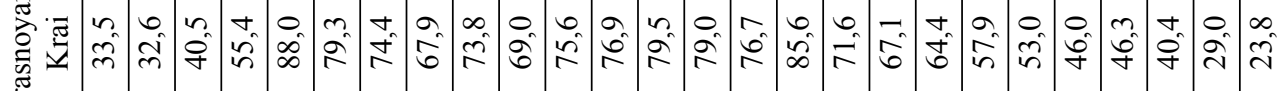
过

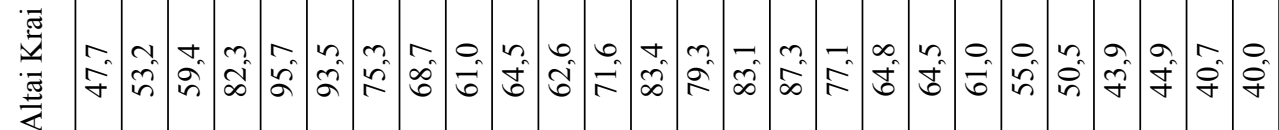

总 
The lowest mortality rates for social reasons among the regions of the Siberian federal district in 2015 were recorded in Tomsk oblast (20.0 deaths per 100 thousand people) and Altai krai (23.8 deaths per 100 thousand people), the rates of these regions being lower than the national average value.

The highest mortality rate for social reasons in 2015 was recorded in Kemerovo oblast (52.8 deaths per 100 thousand people, which is $27.8 \%$ higher than the average value for the Siberian federal district (41.3 deaths per 100 thousand people).

\section{The crime rate}

1243 crimes per 100 thousand people were registered in Russia in 1990. The maximum number of crimes was recorded in 2006 (2695 crimes per 100 thousand people). In 2015 the crime rate "leaders" (per 100 thousand people) were the Siberian federal district (2189 crimes per 100 thousand people), the Far Eastern federal district (2167 crimes per 100 thousand people) and the Ural federal district (1867 crimes per 100 thousand people). The crime rate in these districts for the last 25 years was higher than the national average.

The crime rate in the Siberian Federal district increased by $49.7 \%$ over the last 25 years: from 1462 crimes per 100 thousand people in 1990 to 2189 crimes per 100 thousand people in 2015. In relation to the national indices it amounted to $117.6 \%$ in 1990. In 2015 it was already $134.2 \%$; thus, the increase amounted to 16.6 percentage points (Table 7).

The lowest crime rate among the regions of the Siberian federal district in 2015 was recorded in Altai krai (1631 crimes per 100 thousand people, which is $24.1 \%$ lower than the average for the Siberian federal district (2148 crimes per 100 thousand people)) but 5.0\% higher than the national average values (1554 crimes per 100 thousand people).
A high crime rate (higher than the average in the Siberian federal district) in 2015 was registered in Irkutsk oblast (2219 crimes per 100 thousand people), Krasnoyarsk krai (2176 crimes per 100 thousand people), and Tomsk oblast (2148 crimes per 100 thousand people).

\section{The "violent" ${ }^{\text {crime rate }}$}

The crime rate includes a wide range of crimes ranging from domestic theft, vandalism to robbery and murder. Crimes against a person are among the most serious ones. It is possible to single out a group of "violent" crimes involving harm or risk to a victim's life or health. The analysis provided for including the following categories of crimes of official statistics into a group of "violent" crimes: homicide and murderous assault; malicious harm to health; rape and attempted rape; robbery.

During the last 15 years there was a general trend of decline in the number of "violent" crimes in Russia: from 88 crimes per 100 thousand people in 2000 to 44 crimes per 100 thousand people in 2014. The local maximum of "violent" crimes was registered in 2005 (110.2 crimes per 100 thousand people) (Table 8 ).

There was a significant decrease in the number of "violent" crimes in Russia, the Siberian federal district and all Siberian regions within the period from 2000 to 2014: in Russia the number of crimes decreased two-fold, in the Siberian federal district - by a factor of 1.7.

During this period there was an increase in the "violent" crime rate in the Siberian federal district in relation to the national average indices: in the Siberian federal district the "violent" crime rate increased by 23.7 percentage points: from $141.7 \%$ as per the national average value in 2000 to $165.4 \%$ in 2014 .

The Siberian federal district was a leader in Russia in terms of the number of crimes of this group in the course of 2003-2013, and only 


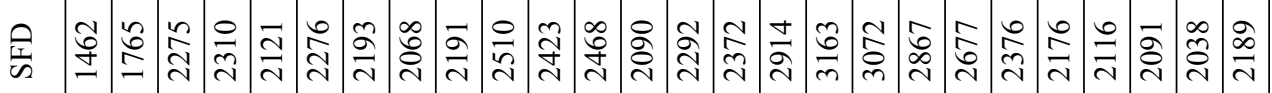

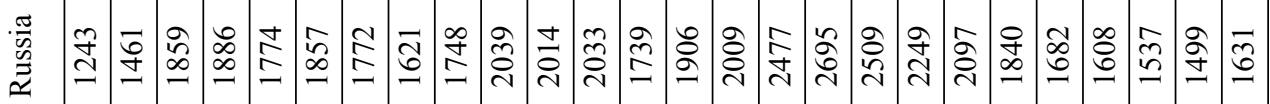

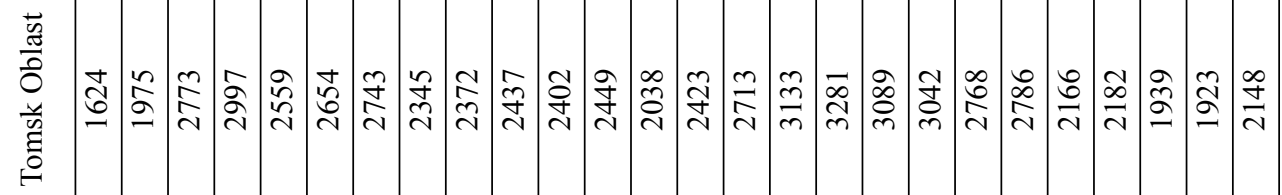

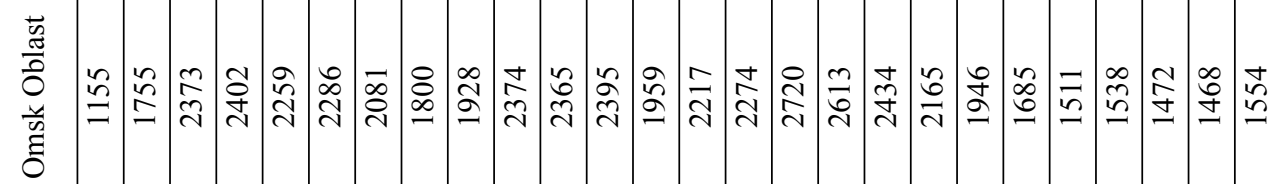

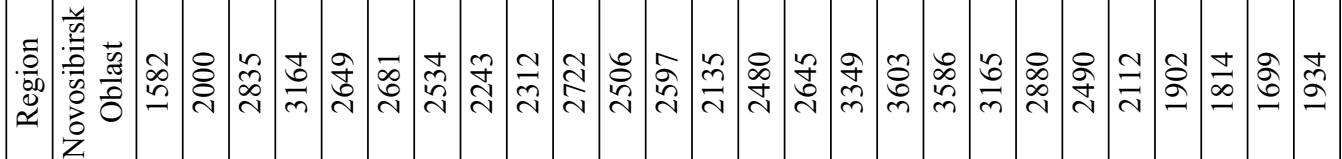

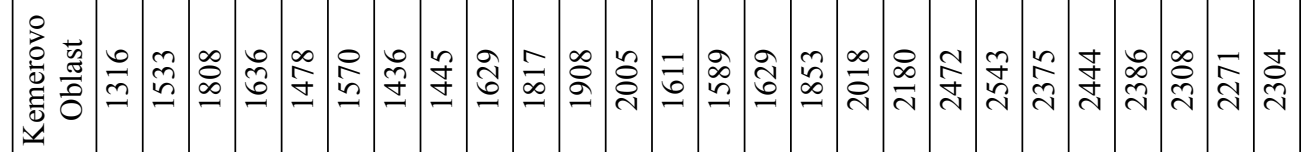

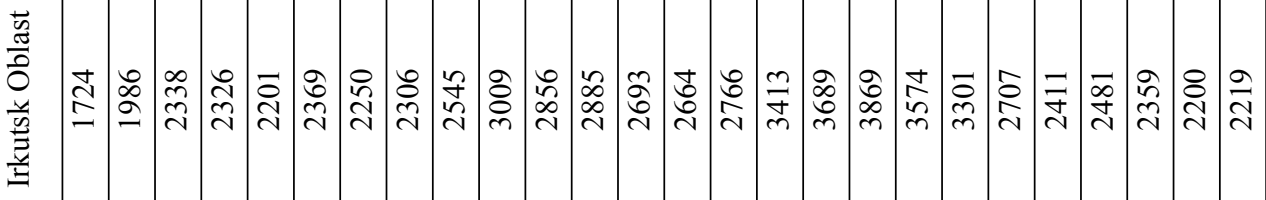

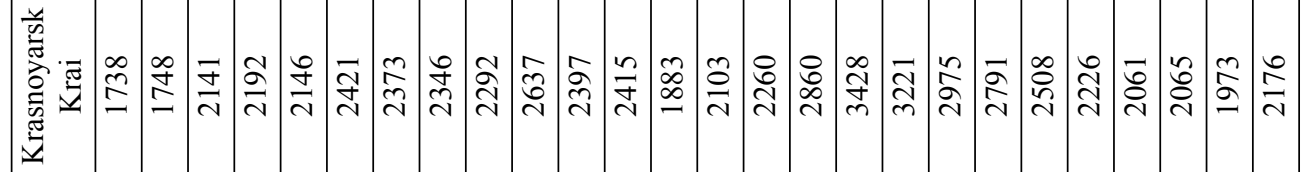

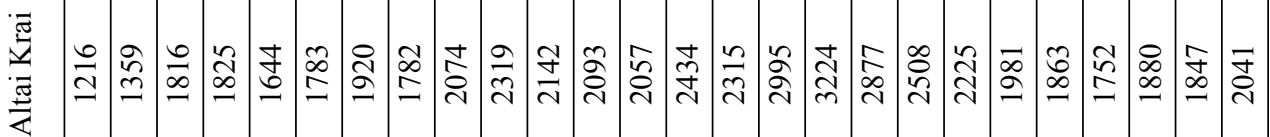

奠 


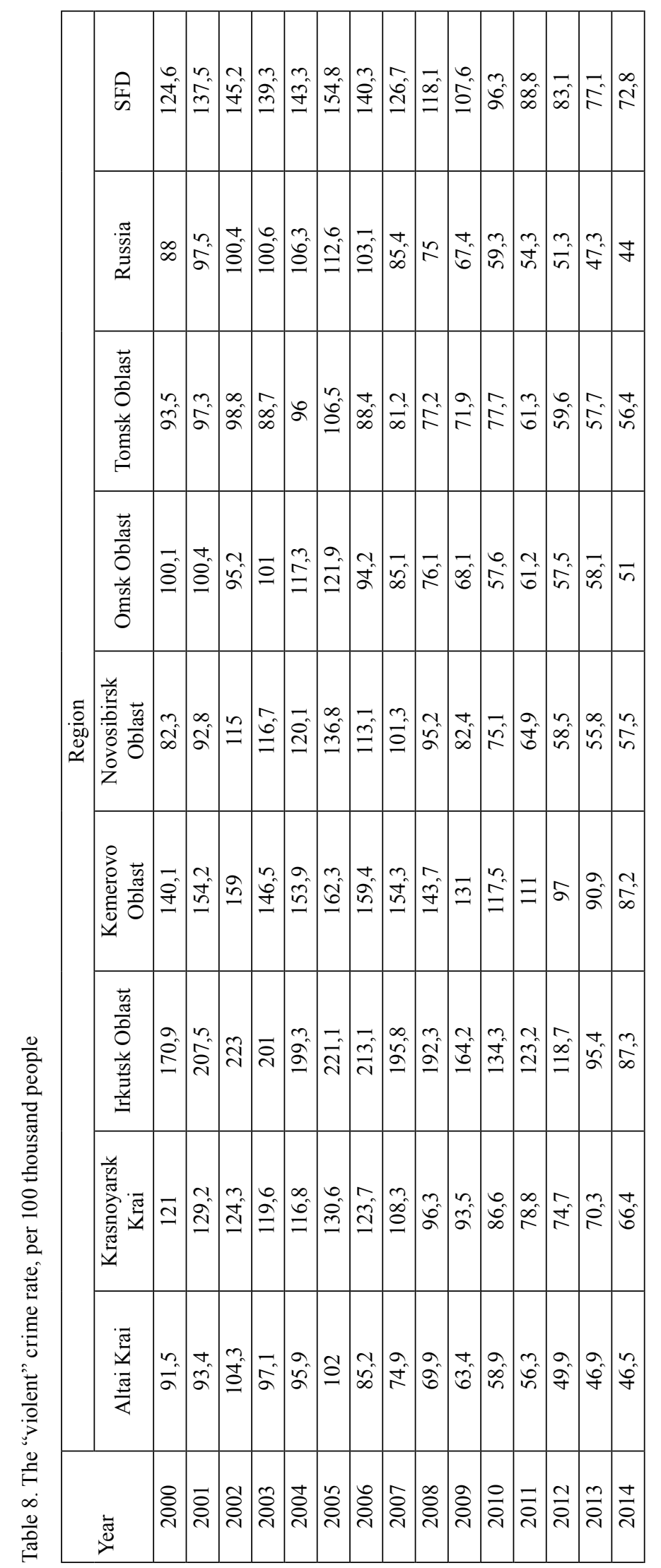


in 2014 the leading position was taken by the Far Eastern federal district (73.8 crimes per 100 thousand people). The rates for other districts were the following ones: 72.8 crimes per 100 thousand people in the Siberian federal district; 58.5 crimes per 100 thousand people in the Ural federal district; 40.0 crimes per 100 thousand people in the North-Western federal district; 39.0 crimes per 100 thousand people in the Volga federal district; 33.9 crimes per 100 thousand people in the Central federal district; 31.8 crimes per 100 thousand people in the Southern federal district; 19.4 crimes per 100 thousand people in the North Caucasian federal district.

The least number of "violent" crimes in 2015 among the regions of the Siberian federal district was recorded in Altai krai, the number being 46.5 crimes per 100 thousand people. It exceeded the national average value by $5.6 \%$ (44 crimes per 100 thousand people) and was $36.1 \%$ below the average for the Siberian federal district (72.8 crimes per 100 thousand people).
The number of "violent" crimes, that was much higher than the average value in Russia (72.8 crimes per 100 thousand people), in 2014 was recorded in two regions, the regions being Irkutsk oblast (87.3 per crimes per 100 thousand people) and Kemerovo oblast (87.2 crimes per 100 thousand people).

\section{Comparison of human potential indices in Siberian regions and the Siberian federal district with the national average indices}

Some of the human potential indices for Siberia (average values) in comparison with the similar indices for Russia are presented in Table 9.

The values for the Siberian federal district differ from the national average ones in all the human potential characteristics and quality of life, the direction of difference being negative. In some cases this difference can reach several tens of percents: the violent crime rate is higher

Table 9. Human potential indices in the Siberian federal district as compared with the national average values

\begin{tabular}{|c|c|c|c|c|}
\hline & Index & $\begin{array}{l}\text { Siberian } \\
\text { federal } \\
\text { district }\end{array}$ & $\begin{array}{l}\text { The national } \\
\text { average } \\
\text { value }\end{array}$ & $\begin{array}{l}\text { The ratio of the values } \\
\text { in the Siberian federal } \\
\text { district to the average } \\
\text { for the Russian } \\
\text { Federation, } \%\end{array}$ \\
\hline 1 & $\begin{array}{l}\text { Per capita monetary income per month, thousand rubles, } \\
2015\end{array}$ & 23.3 & 30.2 & 77.2 \\
\hline 2 & Life expectancy at birth, years, 2015 & 69.3 & 71.4 & 97.1 \\
\hline 3 & $\begin{array}{l}\text { Poverty rate (share of population with the income below } \\
\text { the subsistence minimum), } \%, 2015\end{array}$ & 18.5 & 13.3 & 139.1 \\
\hline 4 & $\begin{array}{l}\text { Share of people with higher education among the employed } \\
\text { in the economy, } \%, 2015\end{array}$ & 29.1 & 33.0 & 88.2 \\
\hline 5 & $\begin{array}{l}\text { Mortality rate for social reasons (accidental alcohol } \\
\text { poisonings, suicides, accidents), persons per } 100 \text { thousand } \\
\text { people, } 2015\end{array}$ & 41.3 & 28.3 & 145.9 \\
\hline 6 & $\begin{array}{l}\text { Crime rate (the number of crimes per } 100 \text { thousand } \\
\text { people), } 2015\end{array}$ & 2189 & 1631 & 134.2 \\
\hline 7 & $\begin{array}{l}\text { The "violent" crime rate (homicide and murderous assault; } \\
\text { malicious harm to health; rape and attempted rape; } \\
\text { robbery) per } 100 \text { thousand people, } 2014\end{array}$ & 72.8 & 44 & 165.5 \\
\hline
\end{tabular}


Table 10. Characteristics of a socio-economic situation in the Siberian federal district

\begin{tabular}{|c|c|c|}
\hline & Processes in Siberia & Commentaries \\
\hline 1 & $\begin{array}{l}\text { A steady trend to decline in the share of the } \\
\text { population of the Siberian federal district in the } \\
\text { total population of Russia due to migration and } \\
\text { natural loss. }\end{array}$ & $\begin{array}{l}\text { Within the period of } 1990-2015 \text { the population of the } \\
\text { Siberian federal district decreased by } 1.8 \text { million people } \\
(8.5 \%) \text { : from } 21.1 \text { million people to } 19.3 \text { million people. }\end{array}$ \\
\hline 2 & $\begin{array}{l}\text { There is a decrease in income per capita in the } \\
\text { Siberian federal district as compared to the income } \\
\text { of an average statistical Russian. }\end{array}$ & $\begin{array}{l}\text { In the } 1990 \text { s the income of the Siberian federal district's } \\
\text { residents was at the national average level. In } 1995 \text { it } \\
\text { was } 4.3 \% \text { below the national average; in } 2015 \text { the gap } \\
\text { increased up to } 22.8 \% \text {. }\end{array}$ \\
\hline 3 & $\begin{array}{l}\text { There is an increase in life expectancy in the } \\
\text { Siberian federal district; yet, it is less stable than } \\
\text { the national average. }\end{array}$ & $\begin{array}{l}\text { Life expectancy at birth in the Siberian federal district } \\
\text { was } 67.9 \text { years in } 1990 \text {, whereas it was } 69.3 \text { years in } \\
2015 \text {. These values were } 1.3 \text { years }(1.9 \%) \text { lower than the } \\
\text { national average in } 1990 \text { and } 2.1 \text { years }(3.0 \%) \text { lower in } \\
2015 \text {. }\end{array}$ \\
\hline 4 & $\begin{array}{l}\text { In Siberia the share of people with higher education } \\
\text { who are employed in the economy remains lower } \\
\text { than the national average. }\end{array}$ & $\begin{array}{l}\text { In recent years in the Siberian federal district the share of } \\
\text { people with higher education among the employed in the } \\
\text { economy does not exceed } 90 \% \text { of the national average. }\end{array}$ \\
\hline 5 & $\begin{array}{l}\text { The share of the poor in the Siberian federal district } \\
\text { is higher than the national average, a decline in } \\
\text { the share of the poor in Russia and Siberia being } \\
\text { a common trend. }\end{array}$ & $\begin{array}{l}\text { In } 2000 \text { the share of the poor in the Siberian federal district } \\
\text { was } 41.6 \% \text {, whereas in Russia it was } 29.0 \% \text {. In } 2015 \text { these } \\
\text { shares were } 18.5 \% \text { and } 13.3 \% \text {, correspondingly. Yet, in } \\
2015 \text { the share of the poor in the Siberian federal district } \\
\text { was } 1.4 \text { times higher than the share of the poor in Russia. }\end{array}$ \\
\hline 6 & $\begin{array}{l}\text { The gap in the rate of the Siberians' mortality for } \\
\text { social reasons (accidental alcohol poisonings and } \\
\text { suicides) relative to the national average value is } \\
\text { growing. That is becoming a social disaster. }\end{array}$ & $\begin{array}{l}\text { In } 1990 \text { the rate of the Siberians' mortality for social } \\
\text { reasons exceeded the national average by } 13.9 \% \text {; by } 2015 \\
\text { the increase amounted to } 46.1 \% \text {. }\end{array}$ \\
\hline 7 & $\begin{array}{l}\text { The crime rate in the Siberian federal district has } \\
\text { been kept at a higher level in comparison with the } \\
\text { national average. }\end{array}$ & $\begin{array}{l}\text { The crime rate in the Siberian federal district in the course } \\
\text { of the last } 25 \text { years was } 18-36 \% \text { higher than the national } \\
\text { average. In } 2009-2015 \text { the Siberian federal district ranked } \\
\text { first as per the crime rate among the federal districts. }\end{array}$ \\
\hline 8 & $\begin{array}{l}\text { The "violent" crime rate (murder and attempted } \\
\text { murder; malicious harm to health; rape and } \\
\text { attempted rape; robbery) in the Siberian federal } \\
\text { district has been kept at a higher level in } \\
\text { comparison with the national average. }\end{array}$ & $\begin{array}{l}\text { The violent crime rate in the Siberian federal district for } \\
\text { the period from } 2000 \text { to } 2015 \text { increased by } 23.7 \text { percentage } \\
\text { points in relation to the national average values: from } \\
141.7 \% \text { in } 2000 \text { to } 165.4 \% \text { in } 2015 \text {. }\end{array}$ \\
\hline
\end{tabular}

by $65.5 \%$; the population's mortality for social reasons is higher by $45.9 \%$; the poverty rate is higher by $39.1 \%$; the crime rate is higher by $34.2 \%$.

Table 10 presents the main characteristics of a socio-economic situation in Siberia as well as their dynamics.

The analysis results show that the quality of life and human potential of Siberia have been in steady decline for the last decades: the relative value of the Siberians' income has been in steady decline, the poverty rate in the Siberian federal district exceeds the national average value; the gap between Siberia and Russia as per the rate of mortality for social reasons (number of suicides and alcohol poisonings per 100 thousand people) has been growing; the share of people with higher education in the Siberian economy is lower in comparison with the national average indices. The crime rate in Siberia is higher than the average value for Russia. Yet, in recent years there has been a significant growth of "violent" crimes (murders, rapes, robberies) in relation to the national average values. 
The revealed trends show that in recent years Siberia has been displaced to the periphery of the country's economic, social and cultural development. Siberia is becoming less developed, crime periphery of the Russian Federation.

\section{From human potential}

to human capital: on some conditions of "human capitalization"

It is important to realize that mere preservation and enhancement of human potential in the form of education and health become fictitious, if there are no conditions for a human's productive self-realization (Efimov, 2010). The population's economic, business and social activity is extremely important for a socio-economic development of the country and its regions. It is this activity that actually ensures "human capitalization", transformation of potential into capital.

Public (national) consensus with respect to the country's future and long-term development goals is an important factor which largely determines the social and economic power of the society. The practice of rapidly developing countries, presented in the World Bank's report (The World Bank, 2014), shows that the national consensus on the long-term development goals is a necessary prerequisite for successful economic modernization. It is public consensus formed in 13 countries that ensured their growth at an average annual rate, and namely not lower than $7 \%$ per year for the course of 30 years in the second half of the XX century (Rysin, 2009). The national consensus on a fundamental trade-off between present and future manifests itself in the citizens' choice between current and future consumption, which makes the implementation of significant investments in the future possible.

The situation, developing in Russia, favours the manifestation of entrepreneurial and social activities in many aspects. It results in a sharp slowdown in the country's economic development within the period of 2012-2015, which is due to internal reasons.

According to the data of $2013,2.6 \%$ of the adult population of Russia (who are not entrepreneurs) had entrepreneurial intentions (intentions to start their business within the next three years), whereas in BRICS countries this index is $21 \%$, in Eastern Europe it amounts to $24 \%$. In recent years Russian students have reoriented towards public service and work in large companies; the level of the students' entrepreneurial intentions in 2013 dropped to $1 \%$ and in 2010 and 2011 it was $8.5 \%$ and $5.7 \%$, respectively. The vast majority of the Russians - more than $90 \%$ - are not involved in entrepreneurial activity and do not even consider this opportunity (Verkhovskaia, et al., 2014).

The Russian population's activity in nonprofit sector is still low. In 2009 the level of their involvement in volunteer activities in nonprofit sector in terms of full-time employment amounted to $0.43 \%$ from the number of economically active population. It is $3-17$ times less than in leading and economically developed countries (Bodrenkova, 2013).

A peculiar feature of the current situation in Russia is the following one: a set of political, legislative and administrative measures resulted in a sharp decline in the value of initiative and entrepreneurial action, rise of paternalistic attitudes and spread of political and social conformism.

Currently in Russia and especially in Siberia there developed an acute shortage of people willing and able to deploy their own economic activity while establishing and managing new businesses, the people being human capital which is the most valuable for the economic development. What is more important in the current situation is to maintain and increase the level of the Siberians' entrepreneurial, innovative, and positive social activity. 


\section{The main provisions of the human capital formation policy}

Taking into consideration the mentioned above, it is possible to formulate some key provisions for the policy of human capital accumulation in the regions of Siberia (Efimov V.S., Kriukov V.A., 2014).

1. Human capital accumulation should be a priority of Siberia's development strategy. A human with his/her education and qualification, initiative and creativity is a basis of the region's productive forces and any development processes. "Closing up" of state expenditures on education and health that is now in progress is inadmissible. It is particularly unacceptable for Siberia.

2. Support of social activity and entrepreneurship should be a priority of the human capital accumulation policy; the elements of paternalism and support of "weak" and vulnerable groups should be maintained, yet the key goal is the creation of the conditions in which an independent, enterprising, and competent human will become a mass phenomenon. Extension and improvement of a "business class" quality is a condition of accelerated development and formation of a diversified economy of Siberia.

3. The subjects of the federation should have broad power and opportunities for the regions' human capital development. Modernization of the system of inter-budget relations, financial resources redistribution in favor of the Russian regions will give them an opportunity to increase "investments" in education and health, healthy lifestyle and recreation, creation of cultural environment to support the population's initiatives, social and entrepreneurial activity.

4. It is necessary to expand a range of measures of demographic and migration policy aimed at supporting birth and family, stimulating the population's migration inflow to Siberia. Increase in labour productivity and use of "low-staffed" technologies (Efimov, 2010) is limited in Siberian conditions. This requires new formats of attracting, filtering and adaptation of migrants, which should prevent the "import" of poverty, crime, and social, ethnic and religious tension.

5. It is necessary to support the metropolitan agglomerations development in Siberia, the agglomerations being the environment that ensures capitalization of a human's education and qualification to the maximum extent. This environment includes the opportunities for entrepreneurial activity, developed labor market, communicative and cultural space of the city (Efimov V.S., et al., 2014; Efimov V.S., Efimov A.V., 2009).

\footnotetext{
For the Programme of the United Nations Development refer to the official website: http://www.un.org/ru/ga/undp/ The number of people with the income below the minimum of subsistence.

The Federal State Statistics Service. Central base of statistical data: http://www.gks.ru/dbscripts/cbsd/DBInet.cgi There is no detailed statistics for mortality for social reasons.

In this work the grouping of the types of crimes does not coincide with the criminological concept of violent crime; the choice of this grouping was determined by the nature of the statistical data available.
}

\section{References}

Becker, G.S. (1964). Human Capital: A Theoretical and Empirical Analysis. N.Y., Columbia University Press.

Becker, G.S. (2003). Chelovecheskoe povedenie: ekonomicheskii podkhod. Izbrannye trudy po ekonomicheskoi teorii [Human Behavior: Economic Approach. Selected Works on the Economic Theory]. Moscow, Higher School of Economics, 672 p. 
Bodrenkova, G.P. (2013). Sistemnoe razvitie dobrovol'chestva v Rossii: ot teorii $k$ praktike [Systematic Development of Volunteering in Russia: from Theory to Practice]. Moscow, ANO "SPO SOTIS", $320 \mathrm{p}$.

Efimov, V.S. (2010). Chelovecheskii capital Krasnoiarskogo kraia: Forsait-issledovanie - 2030. Analiticheskii doklad [The Human Capital of Krasnoyarsk Krai: Foresight Study - 2030. Analytical Report]. Ed. V.S. Efimov. Krasnoyarsk, Siberian Federal University, 126 p.

Efimov, V.S., Dadasheva, V.A., Efimov, A.V. (2014). Krasnoiarsk - 2030: obrazy budushchego. Kontseptsiia i rezul'taty forsait-proekta [Krasnoyark - 2030: Images of the Future. The Conception and Results of a Foresight Project]. "55 I VYSHE” Mezhdunarodnyi etnoantropologicheskii kongress. Sb. ekspert. mat. Proekt "Snezhnyi sezon" 15-16 ianvaria 2014 ["55 AND OVER": International EthnoAnthropological Congress. Expert Materials Collection. The "Snow Season” Project, 15-16 January 2014]. Novosibirsk, MVK “Novosibirsk Expocentre”, 181-197.

Efimov, V.S. Efimov, A.V. (2009). K voprosu o formirovanii Krasnoiarskoi aglomeratsii [On the Formation of Krasnoyarsk Agglomeration], In Vestnik NSUEM, 1, 126-147.

Efimov, V.S. Efimov, A.V. (2013a). Makroregion Sibir' v postsovetskoi Rossii: analiz sotsial'noekonomicheskikh pokazatelei [Macroregion of Siberia in Post-Soviet Russia: Analysis of SocioEconomic Indices]. Makroregion Sibir': problemy i perspektivy razvitiia [Macroregion of Siberia: Problems and Prospects]. Eds. A.V. Uss, V.L. Inozemtsev, E.A. Vaganov [et al.]. Krasnoyarsk, Siberian Federal University, 248-291.

Efimov, V.S., Efimov, A.V. (20136). Sibirskii federal'nyi okrug: analiz sotsial'no-ekonomicheskikh protsessov v 1990-2011 gg. [Siberian Federal District: Analysis of Socio-Economic Processes in 19902011], In Vestnik NSUEM, 3, 10-25.

Efimov, V.S., Kriukov, V.A. (2014). Rossiia: vostochnyi vektor. Predlozheniia k strategii razvitiia Sibiri i Dal'nego Vostoka. Analiticheskii doklad: preprint [Russia: The Eastern Vector. Proposals for the Strategy of Siberia and the Far East Development. Analytical Report: Preprint]. Eds. V.S. Efimov, V.A. Kriukov. Krasnoyarsk, Siberian Federal University, 92 p.

Gimpel'son, V.E., Kapeliushnikov, R.I. (2011). Rossiiskii rabotnik: obrazovanie, professiia, kvalifikatsiia [The Russian Worker: Education, Profession, Qualification]. Moscow, Higher School of Economics, $574 \mathrm{p}$.

Kapeliushnikov, R.I. (2006). Struktura rossiiskoi rabochei sily: osobennosti i dinamika. Preprint WP3/2006/04 [Composition of the Russian Employment: Industrial, Occupational and Educational Characteristics], In Seriia WP3 “Problemy rynka truda" [WP3 Series "Labour Market Problems"]. Moscow, Higher School of Economics, 64 p.

Kapeliushnikov, R.I. (2008). Zapiska ob otechestvennom chelovecheskom kapitale: preprint WP3/2008/01 [Russia's Human Capital: an Assessment: Preprint WP3/2008/01], In Seriia WP3 "Problemy rynka truda" [WP3 Series "Labour Market Problems"]. Moscow, Higher School of Economics, $56 \mathrm{p}$.

Korchagin, Iu.A. (2004). Chelovecheskii capital i protsessy razvitiia na makro- i mikrourovniakh [Human Capital and Development Processes at Macro and Micro Levels]. Voronezh, TsIRE, 106 p.

Korchagin, Iu.A. (2005). Rossiiskii chelovecheskii capital: factor razvitiia ili degradatsii? [Russian Human Capital: Is It a Factor of Development or Degradation?] Voronezh, TsIRE, $252 \mathrm{p}$. 
Rysina, V.T. (2009). Doklad o roste. Strategii ustoichivogo rosta i inkliuzivnogo razvitiia [Report on the Growth. Strategies for Sustained Growth and Inclusive Development]. Ed. V.T. Rysina. Moscow, Ves' mir, 19-20.

Shultz, T.W. (1971). Investment in Human Capital: The Role of Education and of Research. N.Y., London.

Shultz, T.W. (1961). Investment in Human Capital, In American Economic Review, 51 (1), 1-17.

Shultz, T.W. (1963). The Economic Value of Education. N.Y., Columbia University Press.

Soboleva, I.V. (2009). Paradoksy izmereniia chelovecheskogo kapitala. Nauchnyi doklad [Paradoxes of Human Capital Measurement. Scientific Report]. Moscow, Institute of Economics of the Russian Academy of Science, $50 \mathrm{p}$.

Stoun'er, T. (1986). Informatsionnoe bogatstvo: profil' postindustrial'noi ekonomiki [Information Wealth: the Postindustrial Economy Profile]. Novaia tekhnokraticheskaia volna na Zapade [New Technocratic Wave in the West]. Moscow, Progress, $394 \mathrm{p}$.

The World Bank (2013). Review of World Development Report 2014: Risk and Opportunity Managing Risk for Development. Washington, DC, World Bank, 66 p.

Verkhovskaya, O.R., Dorokhin, M.V., Sergeeva, A.V.(2014). Global'nyimonitoring predprinimatel'stva. Rossiia 2013. Natsional'nyi otchet [Global Monitoring of Entrepreneurship. Russia 2013. National Report]. St.-Petersburg, Higher School of Management of St.-Petersburg State University, 64 p.

\title{
Человеческий потенциал
}

\section{и качество жизни в сибирских регионах:} от деградации к росту

\author{
А.В. Ефимов, В.С. Ефимов \\ Сибирский федеральный университет \\ Россия, 660041, Красноярск, пр. Свободный, 79
}

На основании статистических данных проведен анализ и показано, что в последние два десятилетия произошло значительное снижение человеческого потенџиала и качества жизни в Сибири в сравнении со среднероссийскими показателями.

Результаты проведенного анализа показывают, что человеческий потенциал и качество жизни в Сибири в последние десятилетия устойчиво снижаются: происходит снижение относительной величины доходов сибиряков; доля бедных в СФО превышает среднероссийские значения; возрастает разрыв между Сибирью и Россией в иелом по показателю смертности по соииальным причинам (число самоубийств и отравлений алкоголем на 100 тыс. нас.); сохраняется более низкая доля людей с высшим образованием в сибирской экономике в сопоставлении со среднероссийским показателями. В Сибири сохраняется более высокий уровень преступности, чем в среднем по России. Причем в последние годы наблюдается значительный рост показателей «насильственных» преступлений (убийства, насилие, разбой) по отношению к среднероссийским значениям.

Выявленные тенденции показывают, что в последние годы происходит вытеснение Сибирь на периферию экономического, сочиального и культурного развития страны. Сибирь становится все менее развитой, криминальной периферией Российской Федераџии. 
Рассмотрены условия «капитализации человека», текущзая ситуация человеческого капитала и потенциила, сложившаяся в России и Сибири. Складывающцаяся в России ситуация во многих аспектах не способствует проявлению предпринимательской и социальной активности населения, что выражается в резком снижении темпов экономического развития страны 6 период 2012-2015 г2.

Сформулированы положения политики роста человеческого капитала в Сибирском федеральном округе:

- нарашивание человеческого капитала - приоритетная задача стратегии развития Сибири; приоритетом политики наращчвания человеческого капитала является поддержка соииальной активности и предпринимательства;

- субъекты Федерации должны иметь иирокие полномочия и возможности для развития человеческого капитала регионов;

- необходимо расиирять круг мер демографической и миграционной политики, направленных на поддержку рождаемости и поддержку семьи, стимулирование миграционного притока населения в Сибирь;

- необходима поддержка развития в Сибири городских агломераций как среды, в максимальной степени обеспечивающей капитализацию человека.

Ключевые слова: качество жизни, человеческий потенциал, человеческий капитал, социальная политика, регионь Сибири, Сибирский федеральный округ.

Научная специальность: 08.00.00 - экономические науки. 